\title{
Reduced protein diet with near ideal amino acid profile improves energy efficiency and mitigate heat production associated with lactation in sows
}

\author{
Sai Zhang ${ }^{1}$, Jay S. Johnson ${ }^{2}$, Mu Qiao ${ }^{3}$ and Nathalie L. Trottier ${ }^{1 *}$ (D)
}

\begin{abstract}
Background: The study objective was to test the hypothesis that 1) lowering dietary crude protein (CP) increases dietary energetic efficiency and reduces metabolic heat associated with lactation, and 2) excessive dietary leucine (Leu) supplementation in a low CP diet decreases dietary energetic efficiency and increases metabolic heat associated with lactation.

Methods: Fifty-four lactating multiparous Yorkshire sows were allotted to 1 of 3 isocaloric diets $(10.80 \mathrm{MJ} / \mathrm{kg}$ net energy): 1) control (CON; $18.75 \%$ CP), 2) reduced CP with a near ideal or optimal AA profile (OPT; $13.75 \%(\mathrm{CP})$ and 3) diet OPT with excessive Leu (OPTLEU; 14.25\% CP). Sow body weight and backfat were recorded on day 1 and 21 of lactation and piglets were weighed on day 1, 4, 8, 14, 18, and 21 of lactation. Energy balance was measured on sows during early (day 4 to 8 ) and peak (day 14 to 18) lactation, and milk was sampled on day 8 and 18.

Results: Over 21-day lactation, sows fed OPT lost body weight and body lipid $(P<0.05)$. In peak lactation, sows fed OPT had higher milk energy output $(P<0.05)$ than CON. Sows fed OPTLEU tended $(P=0.07)$ to have less milk energy output than OPT and did not differ from CON. Maternal energy retention was lower $(P<0.05)$ in OPT and OPTLEU compared to CON sows, and did not differ between OPTLEU and OPT sows. Sows fed OPT had higher $(P<0.05)$ apparent energy efficiency for milk production compared to CON. Heat production associated with lactation was lower $(P<0.05)$ or tended to be lower $(P=0.082)$, respectively, in OPT and OPTLEU compared to CON sows.

Conclusion: The OPT diet, in peak lactation, improved dietary energy utilization for lactation due to less urinary energy and metabolic heat loss, and triggered dietary energy deposition into milk at the expense of maternal lipid mobilization. Leucine supplementation above requirement may reduce dietary energy utilization for lactation by decreasing the energy partitioning towards milk, partially explaining the effectiveness of OPT diet over CON diets.
\end{abstract}

Keywords: Amino acid, Energy balance, Heat production, Lactating sows, Leucine, Reduced protein diet

\section{Background}

Lactation is an energetically costly process that depends on the sow's ability to consume enough energy to sustain milk production. Voluntary feed intake, however, is biologically limiting [1] and the sow must rely of her body fat and protein when milk energy demand exceeds energy intake. Over the past decades, larger litter size at birth due to genetic

\footnotetext{
* Correspondence: trottier@msu.edu

${ }^{1}$ Department of Animal Science, Michigan State University, East Lansing 48824, USA

Full list of author information is available at the end of the article
}

selection have increased lactation demands [2, 3]. Strategies to improve the efficiency of dietary energy utilization are needed to sustain greater levels of milk production.

Lowering dietary crude protein $(\mathrm{CP})$ in growingfinishing pigs improves energetic efficiency (i.e., retained tissue net energy:gross energy intake) due to reduced heat and urinary energy loss $[4,5]$. Feeding diets with reduced $\mathrm{CP}$ concentrations and improved amino acid (AA) balance to lactating sows increases the efficiency of nitrogen $(\mathrm{N})$ and indispensable amino acid (IDAA) utilization [6-8], and also appears to increase nutrient partitioning towards

(c) The Author(s). 2020 Open Access This article is distributed under the terms of the Creative Commons Attribution 4.0 International License (http://creativecommons.org/licenses/by/4.0/), which permits unrestricted use, distribution, and reproduction in any medium, provided you give appropriate credit to the original author(s) and the source, provide a link to the Creative Commons license, and indicate if changes were made. The Creative Commons Public Domain Dedication waiver (http://creativecommons.org/publicdomain/zero/1.0/) applies to the data made available in this article, unless otherwise stated. 
mammary metabolism $[6,8]$. However, the impact of feeding such diet on energy partitioning and efficiency still need further investigation. In addition, near ideal amino acid (NIAA) profile may also reduce heat production due to changes in metabolic demand resulting from less AA destined to oxidation.

It was previously hypothesized [8] that the improved AA utilization efficiency from feeding reduced $\mathrm{CP}$ diets may be associated with lower intake of leucine (Leu). The premise was based on the notion that high Leu concentrations inhibit lysine (Lys) uptake in rat mammary explants $[9,10]$, and that potential competitive inhibition exists between Lys and Leu utilization by the mammary gland [11, 12]. In the previous study [8], addition of Leu to a reduced CP diet did not have noticeable impact on Lys efficiency, but milk yield in peak lactation was reduced and similar to that of sows fed a conventional diet, indicating some energy partitioning away from the mammary gland. In contrast, the reduced $\mathrm{CP}$ diet without added Leu led to greater milk yield, milk fat and lactose output and litter growth rate, but also resulted in body weight (BW) and back fat losses during peak lactation. What was noticeably greater was the milk fat concentration and milk fat yield in sows fed the reduced $\mathrm{CP}$ diet. Estimation of body lipid mobilization is needed to further understand the potential impact of feeding an improved AA profile on energy partitioning.

The study objective was to estimate dietary energetic efficiency, energy partitioning and heat production for lactation in sows fed a conventional diet with Leu:Lys of 1.63 (control), a reduced CP diet meeting the minimum requirement for standardized ileal digestible (SID) Leu [13] and with Leu:Lys of 1.14 (optimal), and a reduced CP diet with a SID Leu concentration and ratio to Lys to be the as that of control (i.e., 1.63) (optimal + Leu). We hypothesized that 1) lowering $\mathrm{CP}$ to meet the minimum SID Leu requirement and Leu:Lys of 1.14, increases dietary energetic efficiency for lactation and reduces heat production associated with lactation compared to a high CP diet with Leu:Lys of 1.63, and 2) supplementation of Leu to the reduced CP diet to meet Leu:Lys of 1.63 reduces dietary energy partitioning towards milk compared to the reduced CP diet with Leu:Lys of 1.14 .

\section{Methods}

\section{Animals and feeding}

Fifty-four purebred multiparous (parity $3.4 \pm 0.6$ ) Yorkshire sows were selected at day 105 of gestation, balanced by parity and randomly assigned to 1 of 3 dietary treatments [control $(\mathrm{CON}), n=18$; Optimal
(OPT), $n=19$; Optimal + Leu (OPTLEU), $n=17]$. Sows were moved to conventional farrowing crates and accustomed to their experimental diets beginning at day 105 of gestation. Within the first $24 \mathrm{~h}$ of farrowing, litters were equalized to 11 piglets with the objective of weaning 10 piglets per sow. Sows were gradually fed $1.88 \mathrm{~kg} / \mathrm{d}$ on day 1 to reach $7.44 \mathrm{~kg} / \mathrm{d}$ on day 21 of lactation according to the NRC model [13], corresponding to an average daily feed intake of $6 \mathrm{~kg} / \mathrm{d}$. Sows were provided 3 meals (07:00, 13:00, and 17:00) daily with actual feed intake and feed refusal recorded before each morning meal. Fresh water was available freely for all sows and piglets. Iron injection and surgical castration were conducted on day 1 and 7 post-farrowing, respectively, according to farm protocol. Piglets were not supplied with creep feed. The BW and backfat thickness of sows were recorded on day 1 and 21, and litter weights were recorded on day $1,4,8,14$, 18, and 21 according to Zhang et al. [8]. Milk yield was estimated for early (between day 4 and 8 ) and peak lactation (between day 14 and 18) as previously reported [8].

\section{Dietary treatments}

Ingredients and calculated nutrient composition of the diets are presented in Table 1. Analyzed total and free AA of the diets are presented in Table 2. The NRC model [13] was used to estimate requirements for AA, net energy (NE), calcium $(\mathrm{Ca})$ and phosphorus $(\mathrm{P})$. The requirements were predicted based on the swine herd performance at the Michigan State University Swine Teaching and Research Center, as follows: sow BW of $210 \mathrm{~kg}$, parity number of 2 and above, and daily intake of $6 \mathrm{~kg} / \mathrm{d}$, litter size of 10, piglet BW gain of $280 \mathrm{~g} / \mathrm{d}$ over a 21-day lactation period, and an ambient temperature of $20^{\circ} \mathrm{C}$. The model predicted a minimum sow BW loss of $7.5 \mathrm{~kg}$ and the protein:lipid in the model was adjusted to the minimum allowable value of near zero. All diets were formulated to contain the same SID Lys $(9 \mathrm{~g} / \mathrm{kg})$ and $\mathrm{NE}(10.80 \mathrm{MJ} / \mathrm{kg})$ concentrations.

The control diet $(\mathrm{CON})$ was formulated using corn and soybean meal as the only sources of Lys to meet NRC [13] SID Lys requirement $(9 \mathrm{~g} / \mathrm{kg})$ and contained $187.5 \mathrm{~g} / \mathrm{kg}$ CP. Valine (Val) nearly met SID requirement of $7.7 \mathrm{~g} / \mathrm{kg}$ (vs. $7.9 \mathrm{~g} / \mathrm{kg}$ ) according to NRC [13]. All other IDAA SID concentrations were in excess relative to NRC [13].

A second diet balanced to reach a NIAA profile was formulated. The NIAA diet was designed by reducing soybean meal relative to corn to meet the minimum SID Leu requirement, which corresponded to a $\mathrm{CP}$ concentration of $137.5 \mathrm{~g} / \mathrm{kg}$. Then, supplemental crystalline source of $L-$ histidine (His), $L$-isoleucine (Ile), L-Lys, $D L$-Met, $L$ phenylalanine (Phe), $L$-threonine (Thr), $L$-tryptophan (Trp) and $L$-Val and were added to meet the minimum 
Table 1 Ingredient composition and nutrient content of control (CON), ptimal (OPT) and Optimal + leucine (OPTLEU) diets (g/kg, asfed basis)

\begin{tabular}{|c|c|c|c|}
\hline & $\mathrm{CON}$ & OPT & OPTLEU \\
\hline \multicolumn{4}{|l|}{ Ingredient composition } \\
\hline Corn, yellow dent & 591.7 & 614.5 & 612.1 \\
\hline Soybean meal ${ }^{1}$ & 300.0 & 140.0 & 140.0 \\
\hline Soy hulls & - & 105.7 & 105.7 \\
\hline Sugar food product ${ }^{2}$ & 50.0 & 50.0 & 50.0 \\
\hline Beef tallow & 33.5 & 50.2 & 48.1 \\
\hline L-Lysine.HCl, 78.8\% & - & 4.7 & 4.7 \\
\hline L-Valine & - & 2.9 & 2.9 \\
\hline L-Threonine & - & 2.0 & 2.0 \\
\hline L-Phenylalanine & - & 1.3 & 1.3 \\
\hline DL-Methionine & - & 1.1 & 1.1 \\
\hline L-Isoleucine & - & 0.8 & 0.8 \\
\hline L-Histidine & - & 0.7 & 0.7 \\
\hline L-Tryptophan & - & 0.5 & 0.5 \\
\hline L-Leucine & - & - & 4.5 \\
\hline Limestone & 11.8 & 9.3 & 9.3 \\
\hline Dicalcium phosphate & 4.5 & 7.8 & 7.8 \\
\hline Sodium chloride & 5.0 & 5.0 & 5.0 \\
\hline Vitamin and mineral Premix ${ }^{3}$ & 2.5 & 2.5 & 2.5 \\
\hline Titanium dioxide & 1.0 & 1.0 & 1.0 \\
\hline \multicolumn{4}{|l|}{ Calculated nutrient $^{4}$} \\
\hline Net energy, MJ/kg & 10.8 & 10.8 & 10.8 \\
\hline Crude protein & 192.4 & 140.0 & 143.4 \\
\hline Fermentable fiber & 115.8 & 115.8 & 115.7 \\
\hline \multicolumn{4}{|l|}{$\mathrm{SID}^{5}$ amino acids } \\
\hline Arginine & 11.7 & 7.1 & 7.1 \\
\hline Histidine & 4.7 & 3.7 & 3.7 \\
\hline Isoleucine & 7.1 & 5.2 & 5.2 \\
\hline Leucine & 14.7 & 10.3 & 14.7 \\
\hline Lysine & 9.0 & 9.0 & 9.0 \\
\hline Methionine ${ }^{6}$ & 2.7 & 3.0 & 3.0 \\
\hline Methionine + cysteine & 5.4 & 4.9 & 4.9 \\
\hline Phenylalanine & 8.4 & 6.7 & 6.7 \\
\hline Phenylalanine + tyrosine & 13.8 & 10.3 & 10.3 \\
\hline Threonine & 6.1 & 5.8 & 5.8 \\
\hline Tryptophan & 2.1 & 1.7 & 1.7 \\
\hline Valine & 7.7 & 7.9 & 7.9 \\
\hline Nitrogen & 26.3 & 18.8 & 19.3 \\
\hline Total calcium ${ }^{7}$ & 6.5 & 6.5 & 6.5 \\
\hline STTD $^{8}$ phosphorus ${ }^{7}$ & 2.3 & 2.3 & 2.3 \\
\hline
\end{tabular}

${ }^{1} 480 \mathrm{~g} / \mathrm{kg}$ crude protein

${ }^{2}$ Supplied per kg: net energy $11.9 \mathrm{MJ}$; fermentable fiber $0.5 \mathrm{~g} / \mathrm{kg}$; crude protein $10 \mathrm{~g} / \mathrm{kg}$ (International Ingredient Corporation, St. Louis, MO, USA)

${ }^{3}$ Sow micro 5 and Se-yeast PIDX15 (Provimi North America, Inc. Brookville, OH, USA)

${ }^{4}$ Based on nutrient concentrations in feed ingredients according to NRC [13]

${ }^{5}$ SID: standardized ileal digestible

${ }^{6}$ Methionine concentration in Optimal and Optimal + Leucine is higher than Control because methionine was added to meet requirement of (methionine + cysteine)

${ }^{7}$ Additional calcium $(1.0 \mathrm{~g} / \mathrm{kg})$ and phosphorus $(1.5 \mathrm{~g} / \mathrm{kg})$ releases were accounted due to phytase from the premix

${ }^{8}$ STTD: standard total tract digestible 
Table 2 Analyzed and calculated concentration of nitrogen, total and free amino acids in control (CON), optimal (OPT) and optimal + leucine (OPTLEU) diets ${ }^{1}(\mathrm{~g} / \mathrm{kg}$, as-fed basis)

\begin{tabular}{|c|c|c|c|c|c|c|}
\hline & \multicolumn{2}{|l|}{ CON } & \multicolumn{2}{|l|}{ OPT } & \multicolumn{2}{|l|}{ OPTLEU } \\
\hline & Analyzed & Calculated $^{2}$ & Analyzed & Calculated $^{2}$ & Analyzed & Calculated $^{2}$ \\
\hline \multicolumn{7}{|l|}{ Total } \\
\hline Dry matter & 887.6 & - & 889.5 & - & 891.5 & - \\
\hline Nitrogen & 30.0 & 30.8 & 22.0 & 22.4 & 22.8 & 22.9 \\
\hline Arginine & 12.3 & 12.6 & 7.5 & 7.8 & 8.0 & 7.8 \\
\hline Histidine & 4.9 & 5.3 & 3.9 & 4.3 & 4.0 & 4.3 \\
\hline Isoleucine & 8.5 & 8.1 & 6.1 & 6.0 & 6.4 & 6.0 \\
\hline Leucine & 16.5 & 16.7 & 11.4 & 11.9 & 15.9 & 16.4 \\
\hline Lysine & 11.1 & 10.4 & 10.8 & 10.1 & 11.1 & 10.1 \\
\hline Methionine & 2.7 & 3.1 & 2.7 & 3.3 & 3.1 & 3.3 \\
\hline Methionine + cysteine & 5.6 & 6.3 & 4.8 & 5.7 & 5.2 & 5.7 \\
\hline Phenylalanine & 9.8 & 9.6 & 7.5 & 7.6 & 7.7 & 7.6 \\
\hline Phenylalanine + tyrosine & 16.0 & 15.9 & 11.9 & 12.0 & 12.3 & 12.0 \\
\hline Threonine & 7.2 & 7.3 & 6.4 & 6.8 & 6.6 & 6.8 \\
\hline Tryptophan & 2.5 & 2.3 & 1.8 & 1.9 & 1.8 & 1.9 \\
\hline Valine & 9.4 & 9.0 & 8.9 & 8.9 & 9.2 & 8.9 \\
\hline \multicolumn{7}{|l|}{ Free amino acids } \\
\hline Arginine & 0.3 & - & 0.1 & - & 0.1 & - \\
\hline Histidine & - & - & 0.7 & 0.7 & 0.7 & 0.7 \\
\hline Isoleucine & 0.1 & - & 0.8 & 0.8 & 0.8 & 0.8 \\
\hline Leucine & 0.1 & - & 0.1 & - & 4.3 & 4.5 \\
\hline Lysine & 0.2 & - & 3.6 & 3.7 & 3.7 & 3.7 \\
\hline Methionine ${ }^{3}$ & - & - & 0.7 & 1.1 & 0.7 & 1.1 \\
\hline Methionine + cysteine & - & - & 0.7 & 1.1 & 0.7 & 1.1 \\
\hline Phenylalanine & - & - & 1.2 & 1.3 & 1.2 & 1.3 \\
\hline Phenylalanine + tyrosine & 0.1 & - & 1.2 & 1.3 & 1.2 & 1.3 \\
\hline Threonine & 0.2 & - & 2.0 & 2.0 & 2.0 & 2.0 \\
\hline Tryptophan $^{4}$ & - & - & - & 0.5 & - & 0.5 \\
\hline Valine & - & - & 2.7 & 2.9 & 2.7 & 2.9 \\
\hline
\end{tabular}

${ }^{1}$ Analyzed values represents average across 3 blocks (feed mixes)

${ }^{2}$ Calculated values for the total amino acids are based on the amino acids concentration in feed ingredients according to NRC [13], and calculated values for the free amino acids correspond to the dietary inclusion rate in crystalline form

${ }^{3}$ Addition of $D L$-Methionine was omitted in one of the 3 blocks, thus reducing the overall free methionine concentration across all 3 blocks. The average free methionine concentration between blocks 1 and 3 was 0.11 and was zero in block 2. Therefore, across blocks 1, 2 and 3, average free Met was 0.07

${ }^{4}$ Analysis of free tryptophan was not performed

SID requirement for those AA in the NIAA diet. Crystalline $D L$-methionine was added to meet the requirement of Met + cysteine (Cys). This diet is referred to as the optimal diet (OPT) throughout the remainder of the manuscript.

A third diet was formulated to be the same as OPT with added crystalline $L$-leucine to equate the SID Leu concentration of CON and referred to as OPTLEU. Sugar food product (International Ingredient Corporation, St. Louis, MO, USA) was included in all 3 diets at $50 \mathrm{~g} / \mathrm{kg}$ to increase diet palatability. Titanium dioxide was included at $1 \mathrm{~g} / \mathrm{kg}$ as an indigestible index in all diets.

\section{Energy balance procedure and milk sampling}

Energy balance was performed during early lactation (between day 4 and 8) and peak lactation (between day 14 and 18) on a total of 33 sows. Urinary catheter insertion, urine collection and sow milk sampling were carried out as previously reported [8].

\section{Energy, nutrient and titanium analysis}

Feed, fecal and urinary samples were analyzed for gross energy (GE) by bomb calorimetry according to the manufacturer's instructions (Parr Instrument Inc., Moline, IL, USA). Dry matter, $\mathrm{N}$ and titanium in feed and fecal 
samples were analyzed according to Zhang et al. [8]. Dietary AA analysis [14] was performed by the Agricultural Experiment Station Chemical Laboratories (University of Missouri-Columbia, Columbia, MO, USA) as outlined by Zhang et al. [8]. Whole milk samples were analyzed for fat, true protein, lactose, and milk urea $\mathrm{N}$ (MUN) with infrared spectroscopy by the Michigan Dairy Herd Improvement Association (NorthStar Cooperative ${ }^{\bullet}$ Lansing, MI, USA) [8].

\section{Calculations}

Calculation of body protein (BP) and lipid (BL) composition were predicted by empty body weight $(\mathrm{EBW})$ and backfat [13] using the following equations:

$$
\begin{aligned}
E B W(\mathrm{~kg})=0.96 \times & \text { maternal BW }(\mathrm{kg}) \\
\text { Maternal BL }(\mathrm{kg})= & -26.4(\mathrm{~kg})+0.221 \\
& \times \text { maternal } E B W(\mathrm{~kg}) \\
& +1.331(\mathrm{~kg} / \mathrm{mm}) \\
& \times P 2 \text { backfat }(\mathrm{mm})
\end{aligned}
$$

Maternal BP $(\mathrm{kg})=2.28(\mathrm{~kg})$

$$
\begin{aligned}
& +0.178 \times \text { maternal EBW }(\mathrm{kg}) \\
& -0.333(\mathrm{~kg} / \mathrm{mm}) \\
& \times P 2 \text { backfat }(\mathrm{mm})
\end{aligned}
$$

Maternal BL or BP change $(\mathrm{kg})=d 21$ of maternal BL or BP $(\mathrm{kg})$ -d 1 of maternal $B L$ or $B P(\mathrm{~kg})$

$$
\begin{aligned}
& \text { Maternal BP or BL Composition (\%) } \\
& =\frac{\text { Maternal BP or BL }(\mathrm{kg})}{E B W(\mathrm{~kg})} \times 100 \%
\end{aligned}
$$

Calculation of total and maternal energy retention were performed as follows:

$$
\begin{aligned}
& \text { Total energy retention }(M J / d) \\
& =\text { energy intake }(M J / d) \\
& \quad \text {-fecal energy output }(M J / d) \\
& \quad \text {-urinary energy output }(M J / d) \\
& \quad \text { - energy for maintenance }(M J / d)
\end{aligned}
$$

$$
\begin{aligned}
\text { Maternal energy retention }(M J / d)= & \text { energy intake }(M J / d) \\
& - \text { fecal energy output }(M J / d) \\
& \text {-urinary energy output }(M J / d) \\
& \text {-energy for maintenance }(M J / d) \\
& \text {-milk energy output }(M J / d)
\end{aligned}
$$

Metabolizable energy (ME) value of diets for maintenance $(\mathrm{MJ} / \mathrm{kg}$ feed) and ME requirement per day $(\mathrm{MJ} / \mathrm{d})$ was calculated based on metabolic body weight $\left(\mathrm{BW}^{0.75}\right)$ as follows:

$$
\begin{aligned}
& \text { ME for maintenance }(M J / \mathrm{kg} \text { feed }) \\
& =\frac{\text { Daily ME for mainteance }(M J / d)}{\text { Daily intake }(\mathrm{kg} / \mathrm{d})}
\end{aligned}
$$

Daily ME for maintenance $(M J / d)=0.419 \times B W^{0.75}$

The NE value of diets for lactation was calculated as follows:

Dietary NE for lactation $(M J / k g$ feed $)=N E$ in milk $(M J / k g$ feed $)$

$$
\text { -NE mobilized (MJ/kg feed) }
$$

Where,

$$
\begin{aligned}
& N E \text { in milk }(M J / k g \text { feed })=\frac{\text { Daily energy output in milk }(M J / d)}{\text { Daily intake }(\mathrm{kg} / \mathrm{d})} \\
& N E \text { mobilized }(M J / \mathrm{kg} \text { feed }) \\
& =\frac{\text { Daily energy mobilized }(M J / d)}{\text { Daily intake }(\mathrm{kg} / \mathrm{d})}
\end{aligned}
$$

Apparent energy efficiency for milk was calculated as follows:

$$
\begin{aligned}
& \text { Apparent energy efficiency }(\%) \\
& =\frac{\text { Milk energy output }(M J / d)}{\text { Energy intake or absorbed }(M J / d)} \times 100 \%
\end{aligned}
$$

Apparent energy efficiency does not account for the milk energy originating from mobilized body pool and energy lost in urine. To determine true energy efficiency for milk, energy mobilized from the body was removed from the daily energy in milk, and energy for maintenance was removed from ME intake as follows:

True energy efficiency $(\%)=\frac{\text { Daily dietary energy in milk }(M J / d)}{\text { Daily dietary ME for milk }(M J / d)} \times 100 \%$

Where,

$$
\begin{aligned}
& \text { Daily dietary energy in milk }(M J / d)=\text { Daily energy in milk } \\
& (M J / d) \text {-daily milk energy mobilized from body }(M J / d) \\
& \text { Daily dietary } M E \text { for milk }(M J / d)=\text { Daily } M E \text { intake }(M J / d) \\
& \text {-daily ME for maintenance }(M J / d)
\end{aligned}
$$

Energy in milk was calculated by summing energy in milk protein $(23.86 \mathrm{~kJ} / \mathrm{g})$, fat $(39.77 \mathrm{~kJ} / \mathrm{g})$ and lactose $(16.54 \mathrm{~kJ} / \mathrm{g})$, respectively [15]. Energy mobilized from the maternal body was calculated based on change in $\mathrm{BP}(\triangle \mathrm{BP})$ and change in BL $(\triangle \mathrm{BL})$ multiplied by $23.44 \mathrm{~kJ} / \mathrm{g}$ protein and $39.36 \mathrm{~kJ} / \mathrm{g}$ fat [16], respectively, with an efficiency of body energy mobilization to milk of 0.87 [13], as follows:

$$
\text { Mobilized energy }(M J / d)=-(\Delta B P \times 5.7 M J / g+\Delta B L \times 9.4 M J / g) \times 0.87
$$

A value of 0 was used for mobilized energy when sow body protein and fat depositions were null or positive. 
The ME for maintenance was calculated based on NRC [13] as follows:

$$
M E_{\text {maintenance }}(M J / d)=0.419 \times B W^{0.75}
$$

The NE for maintenance was calculated based on fasting heat production of sows fed corn-soybean meal basal diet by Wang et al. [17] as follows:

$$
N E_{\text {maintenance }}(M J / d)=0.310 \times B W^{0.75}
$$

The corrected dietary $\mathrm{NE}\left(\mathrm{NE}_{\mathrm{c}}\right)$ was calculated as follows [18]:

$$
N E_{c}(M J / k g \text { feed })=\frac{N E_{\text {maintenance }}(M J / d)+\text { daily milk energy }(M J / d)}{- \text { daily mobilized energy }(M J / d)}
$$

Heat production associated with lactation was calculated as follows:

$$
\begin{aligned}
& \text { Heat Production } \text { lactation }\left[M J /\left(d \cdot B W^{0.75}\right)\right] \\
& =\frac{\text { Daily heat production }}{\text { lactation }(M J / d)} \\
& \text { Sow metabolic body weight }\left(B W^{0.75}\right)
\end{aligned}
$$

Where,

$$
\begin{aligned}
& \text { Daily Heat Production lactation }(M J / d) \\
& \text { = Daily dietary ME for milk }(M J / d) \\
& \text {-Daily dietary energy in milk }(M J / d)
\end{aligned}
$$

\section{Statistical analysis}

Statistical analyses were conducted using the mixed model procedure of SAS (SAS Inst. Inc., Cary, NC, USA) according to the following model:

$$
\begin{aligned}
\mathrm{Y}_{i j k l m}= & \mu+\mathrm{a}_{i}+\mathrm{b}_{j}+\mathrm{p}_{k}+\mathrm{t}_{l}+\mathrm{d}_{m(i j)}+(\mathrm{ab})_{i j}+(\mathrm{ap})_{i k} \\
& +(\mathrm{at})_{i l}+\mathrm{e}_{i j k l m}
\end{aligned}
$$

where $\mathrm{Y}_{i j k l m}$ is the response on animal $m$ of parity $\mathrm{k}$ for treatment $i$ in block $j$ at period $l, \mu$ is the treatment mean, $\mathrm{a}_{i}$ is the fixed effect of dietary treatment $i, \mathrm{p}_{k}$ is the fixed effect of parity $k$ (e.g. early [P $2-3$ ] vs. late parity [P 4-6]), $\mathrm{t}_{l}$ is the fixed effect of period $l$ (e.g., early vs. peak lactation), $\mathrm{b}_{j}$ is the fixed effect of block $j, \mathrm{~d}_{m(i j)}$ is the random effect of animal $m$ nested within treatment $i$

\begin{tabular}{|c|c|c|c|c|c|c|c|}
\hline \multirow[t]{2}{*}{ Item } & \multicolumn{3}{|l|}{ Diet } & \multirow[t]{2}{*}{ SEM $^{2}$} & \multicolumn{3}{|l|}{$P$-value } \\
\hline & $\mathrm{CON}$ & OPT & $\overline{\text { OPTLEU }}$ & & OPT vs. CON & OPT LEU vs. CON & OPTLEU vs. OPT \\
\hline Number of sows & 18 & 19 & 17 & & & & \\
\hline Body protein day $1^{3}, \mathrm{~kg}$ & 38.7 & 38.5 & 39.0 & 1.5 & 0.997 & 0.962 & 0.937 \\
\hline Body protein day $21^{3}, \mathrm{~kg}$ & 38.7 & 38.3 & 39.4 & 1.4 & 0.952 & 0.876 & 0.719 \\
\hline Protein mobilization ${ }^{4}, \mathrm{~g} / \mathrm{d}$ & 5.5 & -12.8 & 21.8 & 21.0 & 0.803 & 0.847 & 0.497 \\
\hline Protein tissue mobilization ${ }^{5}, \mathrm{~g} / \mathrm{d}$ & 27.5 & -64.0 & 109.0 & 105.0 & 0.803 & 0.847 & 0.497 \\
\hline Body lipid day $1^{3}, \mathrm{~kg}$ & 48.1 & 51.2 & 51.6 & 2.0 & 0.548 & 0.477 & 0.985 \\
\hline Body lipid day $21^{3}, \mathrm{~kg}$ & 46.2 & 44.8 & 49.4 & 2.0 & 0.856 & 0.465 & 0.246 \\
\hline Lipid mobilization ${ }^{4}, \mathrm{~g} / \mathrm{d}$ & -88.5 & $-314.1^{*}$ & -113.9 & 74.6 & 0.143 & 0.968 & 0.207 \\
\hline Lipid tissue mobilization ${ }^{5}, \mathrm{~g} / \mathrm{d}$ & -106.2 & $-376.9^{*}$ & -136.7 & 89.5 & 0.143 & 0.968 & 0.207 \\
\hline Sow BW day $1, \mathrm{~kg}$ & 246 & 249 & 252 & 7 & 0.921 & 0.787 & 0.953 \\
\hline Sow BW day 21, kg & 244 & 241 & 251 & 7 & 0.931 & 0.724 & 0.518 \\
\hline Calculated BW change ${ }^{6}, \mathrm{~kg}$ & -1.6 & -9.3 & -0.6 & & & & \\
\hline Actual BW change, kg & -1.6 & $-8.3^{*}$ & -0.6 & 3.0 & 0.282 & 0.969 & 0.216 \\
\hline
\end{tabular}
and block $j,(\text { ap })_{i k}$ is the fixed interactive effect of treatment $i$ with parity $k$, (at) ${ }_{i l}$ is the fixed interactive effect of treatment $i$ with period $l,(\mathrm{ab})_{i j}$ is the random interactive effect of treatment $i$ with block $j$, and $\mathrm{e}_{i j k l m}$ is the random error on animal $m$ of parity $k$ for treatment $i$ in block $j$ at period $l$. When appropriate, a reduced model was used. Specifically, parity and parity $\times$ treatment

Table 3 Sow and litter growth performance of sows fed Control (CON; $187.4 \mathrm{~g} / \mathrm{kg}$ crude protein), Optimal (OPT; $137.8 \mathrm{~g} / \mathrm{kg}$ crude protein) or Optimal + Leucine (OPTLEU; $142.5 \mathrm{~g} / \mathrm{kg}$ ) diets over a 21-day lactation period ${ }^{1}$

${ }^{1}$ Data are least squares means

${ }^{2}$ Maximum value of the standard error of the means

${ }^{3}$ Body protein and lipid on day 1 and 21 were predicted based on sow body weight (BW) and backfat loss [13]

${ }^{4}$ Protein and lipid mobilization represent body protein and lipid loss without associated water, and the values were predicted based on sow body weight (BW) and backfat loss [13]

${ }^{5}$ Protein and lipid tissue mobilization represent body protein and lipid loss including the associated water as follows: $1 \mathrm{~g}$ of protein is associated with $4 \mathrm{~g}$ of water in $5 \mathrm{~g}$ of tissue and $1 \mathrm{~g}$ of fat is associated with $0.2 \mathrm{~g}$ of water in $1.2 \mathrm{~g}$ of tissue [16]

${ }^{6}$ Calculated BW change $(\mathrm{g})=$ (protein tissue mobilization + lipid tissue mobilization) $\times$ lactation length $(21$ day)

*BW change $(P=0.02)$ and lipid (tissue) mobilization $(P<0.01)$ differed from 0 
Table 4 Energy balance of sows fed Control (CON; $187.4 \mathrm{~g} / \mathrm{kg}$ crude protein), Optimal (OPT; $137.8 \mathrm{~g} / \mathrm{kg}$ crude protein) or Optimal + Leucine (OPTLEU; $142.5 \mathrm{~g} / \mathrm{kg}$ ) diets between day 4 and 8 of lactation (early lactation) and between day 14 and 18 of lactation (peak lactation) $)^{1}$

\begin{tabular}{|c|c|c|c|c|c|c|c|}
\hline \multirow[t]{2}{*}{ Item } & \multicolumn{3}{|l|}{ Diet } & \multirow[t]{2}{*}{$\mathrm{SEM}^{2}$} & \multicolumn{3}{|l|}{$P$-value } \\
\hline & $\mathrm{CON}$ & OPT & OPTLEU & & OPT vs. CON & OPT LEU vs. CON & OPTLEU vs. OPT \\
\hline \multicolumn{8}{|l|}{ Early lactation (day 4 to 8 ) } \\
\hline Number of sows & 12 & 11 & 11 & & & & \\
\hline \multicolumn{8}{|l|}{ Input } \\
\hline Feed intake, kg/d & 4.9 & 4.9 & 4.6 & 0.2 & 0.981 & 0.415 & 0.530 \\
\hline Energy intake, $\mathrm{MJ} / \mathrm{d}$ & 84.68 & 83.27 & 79.82 & 3.53 & 0.937 & 0.475 & 0.690 \\
\hline Energy absorbed, MJ/d & 74.52 & 72.40 & 67.81 & 3.36 & 0.869 & 0.268 & 0.536 \\
\hline \multicolumn{8}{|l|}{ Output, kg/d } \\
\hline Feces (dry matter basis) & 0.52 & 0.54 & 0.59 & 0.06 & 0.980 & 0.716 & 0.827 \\
\hline Urine (as-is) & 10.68 & 4.66 & 5.49 & 1.68 & 0.041 & 0.087 & 0.930 \\
\hline Milk (as-is) & 8.82 & 8.86 & 9.51 & 0.85 & 0.999 & 0.762 & 0.789 \\
\hline \multicolumn{8}{|l|}{ Energy concentration, MJ/kg } \\
\hline Feces (dry matter basis) & 19.41 & 20.20 & 20.10 & 0.13 & $<0.001$ & $<0.001$ & 0.756 \\
\hline Urine (as-is) & 0.22 & 0.26 & 0.26 & 0.05 & 0.766 & 0.791 & 0.999 \\
\hline Milk (as-is) & 4.72 & 5.10 & 4.75 & 0.21 & 0.170 & 0.989 & 0.232 \\
\hline \multicolumn{8}{|l|}{ Energy output, MJ/d } \\
\hline Feces & 10.08 & 10.88 & 11.79 & 1.03 & 0.847 & 0.477 & 0.808 \\
\hline Urine & 1.68 & 1.10 & 1.23 & 0.28 & 0.311 & 0.481 & 0.948 \\
\hline Milk & 41.35 & 45.38 & 44.74 & 3.71 & 0.718 & 0.791 & 0.992 \\
\hline Energy for maintenance, $\mathrm{MJ} / \mathrm{d}^{3}$ & 25.94 & 26.76 & 26.02 & 0.59 & 0.442 & 0.992 & 0.502 \\
\hline Total energy retention, $\mathrm{MJ} / \mathrm{d}^{4}$ & 46.92 & 44.66 & 40.37 & 3.57 & 0.926 & 0.113 & 0.222 \\
\hline Maternal energy retention, $\mathrm{MJ} / \mathrm{d}^{5}$ & 5.84 & -0.97 & -1.83 & 3.93 & 0.434 & 0.352 & 0.987 \\
\hline \multicolumn{8}{|l|}{ Peak lactation (day 14 to 18 ) } \\
\hline Number of sows & 11 & 11 & 11 & & & & \\
\hline \multicolumn{8}{|l|}{ Input } \\
\hline Feed intake, kg/d & $6.8^{*}$ & $6.7^{*}$ & $6.3^{*}$ & 0.2 & 0.975 & 0.169 & 0.242 \\
\hline Energy intake, $\mathrm{MJ} / \mathrm{d}$ & $116.79^{*}$ & $114.95^{*}$ & $109.64^{*}$ & 3.50 & 0.898 & 0.216 & 0.418 \\
\hline Energy absorbed, MJ/d & $102.84^{*}$ & $100.22^{*}$ & $93.08^{*}$ & 3.34 & 0.811 & 0.073 & 0.230 \\
\hline \multicolumn{8}{|l|}{ Output, kg/d } \\
\hline Feces (dry matter basis) & $0.72^{*}$ & $0.74^{*}$ & $0.81^{*}$ & 0.06 & 0.969 & 0.463 & 0.605 \\
\hline Urine (as-is) & $12.04^{*}$ & 5.64 & 6.14 & 1.68 & 0.029 & 0.047 & 0.974 \\
\hline Milk (as-is) & $11.68^{*}$ & $13.93^{*}$ & $12.13^{*}$ & 0.85 & 0.077 & 0.893 & 0.178 \\
\hline \multicolumn{8}{|l|}{ Energy concentration, MJ/kg } \\
\hline Feces (dry matter basis) & 19.41 & 20.20 & 20.10 & 0.13 & $<0.001$ & $<0.001$ & 0.756 \\
\hline Urine (as-is) & 0.26 & 0.25 & 0.31 & 0.05 & 0.973 & 0.750 & 0.613 \\
\hline Milk (as-is) & 4.45 & 5.03 & 4.81 & 0.21 & 0.027 & 0.213 & 0.562 \\
\hline \multicolumn{8}{|l|}{ Energy output, MJ/d } \\
\hline Feces & $13.85^{*}$ & $14.87^{*}$ & $16.33^{*}$ & 1.03 & 0.766 & 0.223 & 0.581 \\
\hline Urine & $2.50^{*}$ & 1.29 & $1.77^{\dagger}$ & 0.28 & 0.012 & 0.163 & 0.446 \\
\hline Milk & $51.76^{*}$ & $70.21^{*}$ & $58.09^{*}$ & 3.73 & 0.005 & 0.461 & 0.072 \\
\hline Energy for maintenance, $\mathrm{MJ} / \mathrm{d}^{3}$ & 26.26 & 26.26 & 26.31 & 0.59 & 0.999 & 0.997 & 0.996 \\
\hline Total energy retention, $\mathrm{MJ} / \mathrm{d}^{4}$ & $74.15^{*}$ & $72.51^{*}$ & $65.06^{*}$ & 3.54 & 0.926 & 0.113 & 0.222 \\
\hline Maternal energy retention, $\mathrm{MJ} / \mathrm{d}^{5}$ & $22.51^{*}$ & 2.26 & $7.05^{\dagger}$ & 3.92 & 0.003 & 0.026 & 0.668 \\
\hline
\end{tabular}

${ }^{1}$ Data are least squares means

${ }^{2}$ Maximum value of the standard error of the means

${ }^{3}$ Energy required for maintenance $(\mathrm{MJ} / \mathrm{d})$ was calculated as $0.42 \mathrm{MJ} / \mathrm{kg}^{0.75}[13]$

${ }^{4}$ Total energy retention = energy intake-fecal energy-urinary energy-maintenance energy

${ }^{5}$ Maternal energy retention = energy intake-fecal energy-urinary energy-maintenance energy-milk energy

*Main effect of period (early and late) was significant $(P<0.05)$

${ }^{\dagger}$ Main effect of period (early and late) tended to be significant: urinary energy output (OPTLEU $\left.P=0.054\right)$; maternal energy retention (OPTLEU $P=0.088$ ) 
effects were not significant and therefore were not included in the reduced model for analyses of body tissue mobilization, energy balance, energy partitioning, estimated water output, energy efficiency and estimated total heat production. Pairwise comparisons were performed between diets (OPT vs. CON, OPTLEU vs. CON, and OPTLEU vs. OPT) for different periods of lactation (early, peak, and 21-day overall lactation) and between early and peak lactation for each diet using the slice option in SAS and Tukey adjustment. Simple t-test was conducted to compare the analyzed and calculated NE values. Effects were declared significant at $P \leq 0.05$, and tendencies were declared at $0.05 \leq P \leq 0.10$.

\section{Results}

\section{Experimental diets}

Diet composition and nutrient concentrations are presented in Table 1 and IDAA concentrations are presented in Table 2, as described in Zhang et al. [8].

\section{Body protein and lipid mobilization}

The BP and BL mobilization over 21-day of lactation for all sows are presented in Table 3. Sow BW change, BP and BL mobilization did not differ between treatments. The BW loss and BL mobilization differed from 0 $(P<0.05)$ in sows fed OPT.

\section{Energy balance}

Energy balance results are presented in Table 4. In early lactation, urinary and milk energy concentration and output, and total and maternal energy retention did not differ across diets. In peak lactation, urinary energy concentration did not differ across diets. Sows fed OPT had lower urinary energy output $(P<0.05)$ than $\mathrm{CON}$, while sows fed OPTLEU did not differ from either CON or OPT. Sows fed OPT had higher milk energy concentration $(P<0.05)$ and milk energy output $(P<0.05)$ than CON. Sows fed OPTLEU tended to $(P=0.07)$ have less milk energy output than OPT, and did not differ from $\mathrm{CON}$ in either milk energy concentration or output.

Table 5 Apparent utilization efficiency of nitrogen and energy of sows fed Control (CON; $187.4 \mathrm{~g} / \mathrm{kg}$ crude protein), Optimal (OPT; $137.8 \mathrm{~g} / \mathrm{kg}$ crude protein) or Optimal + Leucine (OPTLEU; $142.5 \mathrm{~g} / \mathrm{kg}$ ) diets between day 4 and 8 of lactation (early lactation) and between day 14 and 18 of lactation (peak lactation) ${ }^{1}$

\begin{tabular}{|c|c|c|c|c|c|c|c|}
\hline \multirow[t]{2}{*}{ Item } & \multicolumn{3}{|l|}{ Diet } & \multirow[t]{2}{*}{$\mathrm{SEM}^{2}$} & \multicolumn{3}{|l|}{$P$-value } \\
\hline & CON & OPT & OPTLEU & & OPT vs. CON & OPT LEU vs. CON & OPTLEU vs. OPT \\
\hline \multicolumn{8}{|l|}{ Early lactation (day 4 to 8 ) } \\
\hline Number of sows & 12 & 11 & 11 & & & & \\
\hline \multicolumn{8}{|l|}{ Nitrogen $(N)$ utilization efficiency ${ }^{3}$} \\
\hline Milk N output/ME intake, g/MJ ${ }^{4}$ & 0.88 & 0.90 & 0.94 & 0.06 & 0.960 & 0.759 & 0.907 \\
\hline Milk N output/NE intake, g/MJ ${ }^{4}$ & 1.17 & 1.18 & 1.24 & 0.08 & 0.997 & 0.824 & 0.869 \\
\hline \multicolumn{8}{|l|}{ Energy utilization efficiency } \\
\hline Total energy retention, \% of energy intake & 55.1 & 53.3 & 50.8 & 1.6 & 0.703 & 0.163 & 0.537 \\
\hline Total energy retention, $\%$ of energy absorbed & 62.6 & 61.5 & 59.6 & 1.6 & 0.847 & 0.298 & 0.606 \\
\hline Milk energy output, \% of energy intake & 49.5 & 55.2 & 54.6 & 3.7 & 0.529 & 0.599 & 0.993 \\
\hline Milk energy output, \% of energy absorbed & 56.2 & 63.4 & 63.6 & 4.4 & 0.461 & 0.442 & 0.999 \\
\hline \multicolumn{8}{|l|}{ Peak lactation (day 14 to 18 ) } \\
\hline Number of sows & 11 & 11 & 11 & & & & \\
\hline \multicolumn{8}{|l|}{ Nitrogen $(\mathrm{N})$ utilization efficiency ${ }^{3}$} \\
\hline Milk N output/ME intake, g/MJ ${ }^{4}$ & 0.86 & $1.05^{*}$ & 0.93 & 0.06 & 0.088 & 0.660 & 0.384 \\
\hline Milk N output/NE intake, g/MJ4 & 1.14 & $1.38^{*}$ & 1.23 & 0.09 & 0.115 & 0.730 & 0.394 \\
\hline \multicolumn{8}{|l|}{ Energy utilization efficiency } \\
\hline Total energy retention, $\%$ of intake & $63.2^{*}$ & $62.8^{*}$ & $58.6^{*}$ & 1.6 & 0.986 & 0.140 & 0.187 \\
\hline Total energy retention, $\%$ of absorbed & $71.8^{*}$ & $72.2^{*}$ & $69.1^{*}$ & 1.6 & 0.973 & 0.369 & 0.265 \\
\hline Milk energy output, \% of energy intake & 44.5 & 62.3 & 53.0 & 3.7 & 0.007 & 0.268 & 0.199 \\
\hline Milk energy output, $\%$ of energy absorbed & 50.7 & 71.5 & 62.2 & 4.4 & 0.006 & 0.167 & 0.304 \\
\hline
\end{tabular}

${ }^{1}$ Data are least squares means

${ }^{2}$ Maximum value of the standard error of the means

${ }^{3}$ Milk $\mathrm{N}=$ Milk true protein $\times 6.25+$ milk urea $\mathrm{N}$

${ }^{4}$ The ME and NE intake were based on calculated values of ME and NE

${ }^{*}$ Main effect of period (early and late) was significant $(P<0.05)$ 
Table 6 Dietary energy partitioning of sows fed Control (CON; $187.4 \mathrm{~g} / \mathrm{kg}$ crude protein), Optimal (OPT; $137.8 \mathrm{~g} / \mathrm{kg}$ crude protein) or Optimal + Leucine (OPTLEU; $142.5 \mathrm{~g} / \mathrm{kg}$ ) diets between day 4 and 8 of lactation (early lactation) and between day 14 and 18 of lactation (peak lactation) ${ }^{1}$

\begin{tabular}{|c|c|c|c|c|c|c|c|}
\hline \multirow[t]{2}{*}{ Item } & \multicolumn{3}{|l|}{ Diet } & \multirow[t]{2}{*}{$\mathrm{SEM}^{2}$} & \multicolumn{3}{|l|}{$P$-value } \\
\hline & $\mathrm{CON}$ & OPT & OPTLEU & & OPT vs. CON & OPT LEU vs. CON & OPTLEU vs. OPT \\
\hline \multicolumn{8}{|l|}{ Early lactation (day 4 to 8 ) } \\
\hline Number of sows & 12 & 11 & 11 & & & & \\
\hline Feed intake, kg/d & 4.9 & 4.9 & 4.6 & 0.10 & 0.899 & 0.102 & 0.135 \\
\hline \multicolumn{8}{|l|}{ Gross energy (GE), MJ/kg } \\
\hline Analyzed & 17.24 & 17.10 & 17.33 & - & - & - & - \\
\hline Calculated & 17.22 & 17.58 & 17.57 & & & & \\
\hline \multicolumn{8}{|l|}{ Digestible energy (DE), MJ/kg } \\
\hline Analyzed & 15.22 & 14.90 & 14.77 & 0.10 & 0.062 & 0.006 & 0.571 \\
\hline Calculated & 15.03 & 14.70 & 14.71 & & & & \\
\hline \multicolumn{8}{|l|}{ Metabolizable energy (ME), MJ/kg } \\
\hline Analyzed & 14.84 & 14.64 & 14.52 & 0.20 & 0.766 & 0.507 & 0.904 \\
\hline Calculated & 14.44 & 14.26 & 14.26 & & & & \\
\hline Corrected net energy $\left(\mathrm{NE}_{\mathrm{c}}\right), \mathrm{MJ} / \mathrm{kg}^{3}$ & 11.56 & 11.36 & 12.63 & 0.69 & 0.977 & 0.511 & 0.405 \\
\hline $\mathrm{NE}_{\text {lactation }}{ }^{4}$ & 7.65 & 7.28 & 8.57 & 0.71 & 0.928 & 0.625 & 0.417 \\
\hline $\mathrm{NE}_{\text {maintenance }}{ }^{5}$ & 3.91 & 4.07 & 4.16 & 0.15 & 0.536 & 0.233 & 0.822 \\
\hline Calculated & 10.80 & 10.80 & 10.80 & & & & \\
\hline \multicolumn{8}{|l|}{ Peak lactation (day 14 to 18 ) } \\
\hline No. of sows & 11 & 11 & 11 & & & & \\
\hline Feed intake, kg/d & 6.8 & 6.7 & 6.3 & 0.1 & 0.865 & 0.034 & 0.049 \\
\hline \multicolumn{8}{|l|}{ Gross energy (GE), MJ/kg } \\
\hline Analyzed & 17.24 & 17.10 & 17.33 & - & - & - & - \\
\hline Calculated & 17.22 & 17.58 & 17.57 & & & & \\
\hline \multicolumn{8}{|l|}{ Digestible energy (DE), MJ/kg } \\
\hline Analyzed & 15.22 & 14.90 & 14.77 & 0.10 & 0.062 & 0.006 & 0.571 \\
\hline Calculated & 15.03 & 14.70 & 14.71 & & & & \\
\hline \multicolumn{8}{|l|}{ Metabolizable energy (ME), MJ/kg } \\
\hline Analyzed & 14.81 & 14.67 & 14.45 & 0.20 & 0.887 & 0.427 & 0.709 \\
\hline Calculated & 14.44 & 14.26 & 14.26 & & & & \\
\hline Corrected net energy $\left(\mathrm{NE}_{\mathrm{c}}\right), \mathrm{MJ} / \mathrm{kg}^{3}$ & $10.01^{*}$ & 12.16 & 11.25 & 0.69 & 0.087 & 0.418 & 0.623 \\
\hline $\mathrm{NE}_{\text {lactation }}{ }^{4}$ & 7.13 & $9.26^{*}$ & 8.13 & 0.71 & 0.105 & 0.584 & 0.506 \\
\hline $\mathrm{NE}_{\text {maintenance }}{ }^{5}$ & $2.88^{*}$ & 2.93 & 3.14 & 0.15 & 0.952 & 0.221 & 0.349 \\
\hline Calculated & 10.80 & 10.80 & 10.80 & & & & \\
\hline
\end{tabular}

${ }^{1}$ Data are least squares means; energy is presented as $\mathrm{MJ} / \mathrm{kg}$ feed

${ }^{2}$ Maximum value of the standard error of the means

${ }^{3} \mathrm{NE}_{\mathrm{c}}(\mathrm{MJ} / \mathrm{kg}$ feed $)=\mathrm{NE}_{\text {milk }}(\mathrm{MJ} / \mathrm{kg}$ feed $)+\mathrm{NE}_{\text {maintenance }}(\mathrm{MJ} / \mathrm{kg}$ feed $)$. NE was higher $(P<0.05)$ than calculated NE in OPTLEU diet during early lactation and tended

to be higher $(P=0.057)$ in OPT diet during peak lactation

${ }^{4} \mathrm{NE}_{\text {lactation }}(\mathrm{MJ} / \mathrm{kg}$ feed $)=\frac{\text { Milk energy output }(\mathrm{MJ} / \mathrm{d})-\text { Milk energy from body }(\mathrm{MJ} / \mathrm{d})}{\text { Daily feed intake }(\mathrm{kg} / \mathrm{d})}$. NE $\mathrm{E}_{\text {lactation }}$ was lower than $(P<0.01)$ calculated $\mathrm{NE}$ in each experimental diet during both early and peak lactation

${ }^{5} \mathrm{NE}_{\text {maintenane }}(\mathrm{MJ} / \mathrm{kg}$ feed $)=\frac{0.310 \times \mathrm{BW}^{0.75}(\mathrm{M} \mathrm{J} / \mathrm{d})}{\text { Daily feed intake }(\mathrm{kg} / \mathrm{d})}$

${ }^{*}$ Main effect of period (early and late) was significant $(P<0.05)$. 
Table 7 The relative values between dietary gross energy (GE), digestible energy (DE), metabolizable energy (ME), and net energy (NE) of sows fed Control (CON; $187.4 \mathrm{~g} / \mathrm{kg}$ crude protein), Optimal (OPT; $137.8 \mathrm{~g} / \mathrm{kg}$ crude protein) or Optimal + Leucine (OPTLEU; $142.5 \mathrm{~g} / \mathrm{kg}$ ) diets between day 4 and 8 of lactation (early lactation) and between day 14 and 18 of lactation (peak lactation) ${ }^{1}$

\begin{tabular}{|c|c|c|c|c|c|c|c|}
\hline \multirow[t]{2}{*}{ Item } & \multicolumn{3}{|l|}{ Diet } & \multirow[t]{2}{*}{$\mathrm{SEM}^{2}$} & \multicolumn{3}{|l|}{$P$-value } \\
\hline & $\mathrm{CON}$ & OPT & OPTLEU & & OPT vs. CON & OPT LEU vs. CON & OPTLEU vs. OPT \\
\hline \multicolumn{8}{|c|}{ Early lactation (day 4 to 8 ) } \\
\hline Number of sows & 12 & 11 & 11 & & & & \\
\hline \multicolumn{8}{|l|}{$\mathrm{DE} / \mathrm{GE}, \%$} \\
\hline Analyzed & 88.3 & 87.2 & 85.2 & 0.4 & 0.162 & $<0.01$ & 0.007 \\
\hline Calculated & 87.3 & 83.6 & 83.7 & & & & \\
\hline \multicolumn{8}{|l|}{$\mathrm{ME} / \mathrm{DE}, \%$} \\
\hline Analyzed & 97.7 & 98.5 & 98.2 & 0.4 & 0.324 & 0.656 & 0.836 \\
\hline Calculated & 96.0 & 97.0 & 97.0 & & & & \\
\hline \multicolumn{8}{|l|}{$\mathrm{NE}_{\text {lactation }} / \mathrm{ME}, \%^{3}$} \\
\hline Analyzed & 51.4 & 49.7 & 58.9 & 4.8 & 0.967 & 0.507 & 0.380 \\
\hline Calculated & 74.8 & 75.8 & 75.7 & & & & \\
\hline$N E_{\text {milk }} / M E_{1} \%^{4}$ & 57.5 & 64.4 & 65.0 & 4.3 & 0.500 & 0.448 & 0.996 \\
\hline \multicolumn{8}{|c|}{ Peak lactation (day 14 to 18 ) } \\
\hline Number of sows & 11 & 11 & 11 & & & & \\
\hline \multicolumn{8}{|l|}{$\mathrm{DE} / \mathrm{GE}, \%$} \\
\hline Analyzed & 88.3 & 87.2 & 85.2 & 0.4 & 0.162 & $<0.01$ & 0.007 \\
\hline Calculated & 87.3 & 83.6 & 83.7 & & & & \\
\hline \multicolumn{8}{|l|}{ ME/DE, \% } \\
\hline Analyzed & 97.5 & 98.7 & 98.0 & 0.4 & 0.063 & 0.635 & 0.327 \\
\hline Calculated & 96.0 & 97.0 & 97.0 & & & & \\
\hline \multicolumn{8}{|l|}{$\mathrm{NE}_{\text {lactation }} / \mathrm{ME}, \%^{3}$} \\
\hline Analyzed & 48.0 & $63.0^{*}$ & 56.2 & 4.8 & 0.092 & 0.468 & 0.584 \\
\hline Calculated & 74.8 & 75.8 & 75.7 & & & & \\
\hline $\mathrm{NE}_{\text {milk }} / \mathrm{ME}, \%^{4}$ & 51.9 & 72.4 & 63.5 & 4.4 & 0.008 & 0.167 & 0.339 \\
\hline $\begin{array}{l}{ }^{1} \text { Data are least square } \\
{ }^{2} \text { Maximum value of th } \\
{ }^{3} \mathrm{NE}_{\text {lactation }}(\mathrm{MJ} / \mathrm{kg} \text { feed } \\
{ }^{4} \mathrm{NE}_{\text {milk }}(\mathrm{MJ} / \mathrm{kg} \text { feed })= \\
{ }^{*} \text { Main effect of period }\end{array}$ & $\begin{array}{l}\text { ror of th } \\
\text { output( }(\mathrm{Mu}) \\
\text { Daily } \\
\text { ut(MJ/d) } \\
\mathrm{e}(\mathrm{kg} / \mathrm{d})\end{array}$ & $\begin{array}{l}\text { ans } \\
\text { ans } \\
\text { energy fro } \\
\text { ke(kg/d) }\end{array}$ & & & & & \\
\hline
\end{tabular}

Total energy retention did not differ across diets. Maternal energy retention was lower $(P<0.05)$ in sows fed low protein diets (OPT and OPTLEU) than those fed CON, and did not differ between OPTLEU and OPT.

\section{Apparent efficiency of nitrogen and energy}

Apparent efficiency of $\mathrm{N}$ and energy utilization results are presented in Table 5. In early lactation, milk $\mathrm{N}$ output relative to ME or NE intake, and apparent energy efficiency for milk did not differ across diets. In peak lactation, milk $\mathrm{N}$ output relative to $\mathrm{NE}$ intake did not differ across diets. Milk $\mathrm{N}$ output relative to ME intake in OPT tended to be higher $(P=0.088)$ than $C O N$, and those in OPTLEU did not differ from either CON or OPT. Sows fed OPT had higher $(P<0.05)$ apparent energy efficiency for milk compared to CON, and sows fed OPTLEU did not differ from either CON or OPT.

\section{Dietary energy partitioning}

Dietary energy partitioning is presented in Tables 6 and 7. In both early and peak lactation (Table 6), digestible energy $(\mathrm{DE})$ value of low protein diets was lower $(P<0.01$; OPTLEU) or tended to be lower $(P=0.06$; OPT $)$ than that of CON. The DE value of OPTLEU did not differ from OPT. The ME values of all diets did not differ. The $\mathrm{NE}_{\mathrm{c}}$ value did not differ between diets in early lactation and tended to be higher $(P=0.09)$ in OPT compared to CON in peak lactation. Compared to the calculated NE values, the $\mathrm{NE}_{\mathrm{c}}$ value was higher $(P<0.05)$ in OPTLEU during 
early lactation and tended to be higher $(P=0.06)$ in OPT during peak lactation.

The energy values of NE, ME, DE expressed relative to ME, DE and GE, respectively, are presented in Table 8. In early lactation, the $\mathrm{ME} / \mathrm{DE}, \mathrm{NE}_{\text {lactation }} / \mathrm{ME}$, and $\mathrm{NE}_{\text {milk }} / \mathrm{ME}$ did not differ across diets. In peak lactation, the ME/DE tended to be higher $(P=0.063)$ in OPT than $\mathrm{CON}$. The ME/DE in OPTLEU did not differ from either CON or OPT. Compared to CON, the $\mathrm{NE}_{\text {milk }} / \mathrm{ME}$ and $\mathrm{NE}_{\text {lactation }} / \mathrm{ME}$ was higher $(P<0.01)$ or tended to be higher $(P=0.092)$, respectively, in OPT. The $\mathrm{NE}_{\text {milk }} / \mathrm{ME}$ and $\mathrm{NE}_{\text {lactation }} / \mathrm{ME}$ in OPTLEU did not differ from either CON or OPT. In both early and peak lactation, the DE/ GE did not differ between CON and OPT, and was lower $(P<0.01)$ in sows fed OPTLEU than those fed CON or $\mathrm{OPT}$. The $\mathrm{NE}_{\text {lactation}} / \mathrm{ME}$ did not differ across diets.

\section{Energy efficiency and estimated heat production associated with lactation}

True energy efficiency and estimated heat production associated with lactation are presented in Table 8. In early lactation, heat production did not differ across diets. In peak lactation, compared to $\mathrm{CON}$, heat production was lower $(P<0.05)$ or tended to be lower $(P=0.082)$ in sows fed OPT and OPTLEU, respectively, and did not differ between OPT and OPTLEU. In both early and peak lactation, true milk energy efficiency did not differ across diets. Over 21-day lactation period, true milk energy efficiency and heat production did not differ across diets.

\section{Discussion}

In a previous study conducted on lactating sows [8], we reported that reducing dietary protein to meet the minimum SID Leu requirement increased utilization efficiency of N, arginine (Arg), His, Ile, Leu, Phe + tyrosine (Tyr) and Trp for milk yield while maintaining overall lactation performance. Supplementing Leu to the reduced CP diet did not impact the efficiency of IDAA utilization but appeared to repartition nutrients away from the mammary gland. In the current work we aimed at determining dietary energetic efficiency, partitioning, and heat production associated with lactation in sows fed a reduced protein diet with a NIAA profile (OPT) and OPT diet with supplemental Leu (OPTLEU). In the present study, the term "near ideal AA profile" was chosen in lieu of the conventional "ideal AA profile" because the "ideal AA profile" is conceptual rather than biologically factual. The rationale is further based on the notions that an "ideal AA profile" 1) cannot be limited to the relative contribution of only two AA pools (i.e., milk and maintenance), 2) needs accurate characterization of the maintenance AA pool for the lactating sow, and 3) should include AA for which dietary essentiality is known for lactating sow [i.e., arginine (Arg) and histidine].
The loss of BW in sows fed OPT was mainly associated with BL rather than BP loss, and BL loss was consistently greater than BP loss across diets, implying that the drive for tissue mobilization was likely due to a deficit in energy supply as suggested by others [19, 20]. Mobilization of BL, which is energy dense compared to protein [16], is more efficient than mobilization of BP to satisfy the energy need for milk production. In fact, milk fat content of sows fed OPT was greater [8], further supporting that the increased BW loss was associated mainly with BL. Sows generally lose more BL than BP throughout lactation [21]. It was reported that [18] the loss of BW in lactating sows fed diets containing $\mathrm{CP}$ from 146 to $186 \mathrm{~g} / \mathrm{kg}$ was due to BL mobilization. On the other hand, Huber et al. [6] reported that sows fed a similar low CP diet as this study lost BW over a 21-day lactation period, and indicated based on loin eye area measurements that the $\mathrm{BW}$ loss resulted from greater body protein as opposed to BL mobilization. The greater BP loss in that study may have been associated with feeding diets marginally deficient in Lys [6]. In contrast, sows fed CON and OPTLEU lost a minimal amount of $\mathrm{BW}$ and were in a positive maternal $\mathrm{N}$ balance [8]. This observation suggested that Leu to Lys of 1.63 may impact partitioning of DE by directing energy away from mammary gland and towards the maternal pool.

In this study, mobilization of BP and BL of sows fed OPT (64 and $377 \mathrm{~g} / \mathrm{d}$, respectively) and CON (28 and 106 $\mathrm{g} / \mathrm{d}$, respectively) was quantified. Our BP mobilization values are in the range reported by Pedersen et al. [17] (i.e., 28 to $64 \mathrm{~g} / \mathrm{d}$ vs. 20 to $40 \mathrm{~g} / \mathrm{d}$ ) for sows fed CP diets ranging from 146 to $186 \mathrm{~g} / \mathrm{kg}$, but those for BL were noticeably lower (i.e., 106 to $377 \mathrm{~g} / \mathrm{d}$ vs. 800 to $820 \mathrm{~g} / \mathrm{d}$ ). It is unclear whether estimation of $\mathrm{BL}$ and $\mathrm{BP}$ mobilization by Pedersen et al. [18] was associated with water or not. In this study, BL and BP were quantified with or without water. The other possible reason may be ascribed to a different prediction approach. The current study predicted BP and BL based on sow BW and P2 backfat thickness equations outlined in NRC [13], while Pedersen et al. [18] included deuterium oxide $\left(\mathrm{D}_{2} \mathrm{O}\right)$ space in addition to sow BW and P2 backfat thickness [21]. Earlier on, Pedersen et al. [22] estimated BL and BP relative to BW. Their values were $15.7 \%$ and $26.8 \%$ for BP and $\mathrm{BL}$, respectively, on day 3 of lactation, and $16.7 \%$ and $20.9 \%$ for BP and BL, respectively, on day 28 of lactation. In our study, on day 1 of lactation, BP and BL were $15.7 \%$ and $19.6 \%$, respectively, for CON, and $15.5 \%$ and $20.6 \%$, respectively, for OPT. On day 21 of lactation, BP and BL were $15.9 \%$ and $18.9 \%$, respectively, for $\mathrm{CON}$, and $15.9 \%$ and $18.6 \%$, respectively, for OPT. Again, the predictions of BP \% are fairly close between our study and those of Pedersen et al. [22], but those of BL\% are lower. It is possible that the approach of NRC [13] may yield lower BL prediction than 
Table 8 True energy efficiency and heat production associated with milk production of sows fed Control (CON; $187.4 \mathrm{~g} / \mathrm{kg} \mathrm{crude}$ protein), Optimal (OPT; $137.8 \mathrm{~g} / \mathrm{kg}$ crude protein) or Optimal + Leucine (OPTLEU; $142.5 \mathrm{~g} / \mathrm{kg}$ ) diets in early (day 4 to day 8), peak (day 14 to day 18) and overall (day 1 to day 21) lactation period ${ }^{1}$

\begin{tabular}{|c|c|c|c|c|c|c|c|}
\hline \multirow[t]{2}{*}{ Item } & \multicolumn{3}{|l|}{ Diet } & \multirow[t]{2}{*}{$\mathrm{SEM}^{2}$} & \multicolumn{3}{|l|}{$P$-value } \\
\hline & $\overline{C O N}$ & OPT & OPTLEU & & OPT vs. CON & OPT LEU vs. CON & OPTLEU vs. OPT \\
\hline \multicolumn{8}{|l|}{ Early lactation (day 4 to 8 ) } \\
\hline Number of sows ${ }^{3}$ & 12 & 11 & 11 & & & & \\
\hline$M E_{\text {milk, }}, M J / d^{4}$ & 46.89 & 44.65 & 40.35 & 3.56 & 0.864 & 0.306 & 0.595 \\
\hline$M E_{\text {intake }}$ & 72.77 & 71.29 & 66.52 & 3.45 & 0.944 & 0.375 & 0.564 \\
\hline$M E_{\text {maintenance }}$ & 25.94 & 26.76 & 26.02 & 0.58 & 0.442 & 0.992 & 0.502 \\
\hline Milk energy output from diet, $\mathrm{MJ} / \mathrm{d}^{5}$ & 37.40 & 35.91 & 41.06 & 4.54 & 0.970 & 0.835 & 0.705 \\
\hline Milk energy output & 41.35 & 45.38 & 44.74 & 3.71 & 0.718 & 0.791 & 0.992 \\
\hline Milk energy output from body & 0.46 & 8.3 & 2.01 & 3.04 & 0.992 & 1.000 & 0.995 \\
\hline True energy efficiency, $\%^{6}$ & 79.9 & 78.8 & 94.0 & 7.0 & 0.993 & 0.333 & 0.293 \\
\hline Milk energy from diet $^{7}$ & 89.8 & 77.2 & 90.6 & 4.7 & 0.167 & 0.992 & 0.132 \\
\hline Milk energy from body & 10.2 & 22.8 & 9.4 & 4.7 & 0.167 & 0.992 & 0.132 \\
\hline Heat production associated with lactation ${ }^{8}, \mathrm{k} /\left(\mathrm{d} \cdot \mathrm{BW} W^{0.75}\right)$ & 160 & 132 & 30 & 64 & 0.944 & 0.319 & 0.504 \\
\hline \multicolumn{8}{|l|}{ Peak lactation (day 14 to 18 ) } \\
\hline Number of sows ${ }^{3}$ & 11 & 11 & 11 & & & & \\
\hline$M E_{\text {milk, }}, M J / d^{4}$ & $74.13^{*}$ & $72.51^{*}$ & $65.06^{*}$ & 3.56 & 0.928 & 0.114 & 0.222 \\
\hline$M E_{\text {intake }}$ & $100.30^{*}$ & $98.96^{*}$ & $91.31^{*}$ & 3.45 & 0.955 & 0.144 & 0.238 \\
\hline$M E_{\text {maintenance }}$ & 26.26 & 26.26 & 26.31 & 0.58 & 0.999 & 0.997 & 0.996 \\
\hline Milk energy output from diet, $\mathrm{MJ} / \mathrm{d}^{5}$ & $47.98^{*}$ & $61.44^{*}$ & $52.34^{*}$ & 4.54 & 0.112 & 0.780 & 0.347 \\
\hline Milk energy output & $51.76^{*}$ & $70.21^{*}$ & $58.09^{*}$ & 3.73 & 0.005 & 0.461 & 0.072 \\
\hline Milk energy output from body & 0.47 & $8.25^{*}$ & 2.00 & 3.04 & 0.992 & 1.000 & 0.995 \\
\hline True energy efficiency, $\%^{6}$ & $65.2^{\dagger}$ & 86.1 & $79.5^{+}$ & 7.0 & 0.106 & 0.329 & 0.786 \\
\hline Milk energy from diet $^{7}$ & 90.6 & $86.8^{*}$ & 90.1 & 4.7 & 0.837 & 0.997 & 0.869 \\
\hline Milk energy from body & 9.4 & $13.2^{*}$ & 9.9 & 4.7 & 0.837 & 0.997 & 0.869 \\
\hline Heat production associated with lactation, $\mathrm{kJ} /\left(\mathrm{d} \cdot \mathrm{BW} \mathrm{W}^{0.75}\right)^{8}$ & $414^{*}$ & 165 & $211^{*}$ & 64 & 0.028 & 0.082 & 0.870 \\
\hline \multicolumn{8}{|l|}{ Over a 21-day lactation } \\
\hline Number of sows ${ }^{3}$ & 11 & 9 & 9 & & & & \\
\hline$M E_{\text {milk, }}, M J / d^{4}$ & 60.79 & 59.15 & 52.25 & 3.68 & 0.924 & 0.229 & 0.349 \\
\hline$M E_{\text {intake }}$ & 86.81 & 85.89 & 78.39 & 3.62 & 0.978 & 0.264 & 0.335 \\
\hline$M E_{\text {maintenance }}$ & 26.07 & 26.74 & 25.95 & 0.64 & 0.670 & 0.987 & 0.617 \\
\hline Milk energy output from diet, $\mathrm{MJ} / \mathrm{d}^{5}$ & 43.11 & 48.43 & 44.38 & 5.50 & 0.736 & 0.982 & 0.843 \\
\hline Milk energy output & 46.93 & 59.34 & 49.56 & 4.91 & 0.153 & 0.873 & 0.272 \\
\hline Milk energy output from body & -0.62 & 9.40 & 1.67 & 3.82 & 0.241 & 0.900 & 0.410 \\
\hline True energy efficiency, $\%$ & 70.5 & 82.2 & 83.2 & 6.3 & 0.439 & 0.390 & 0.993 \\
\hline Milk energy from diet $^{7}$ & 91.6 & 81.6 & 88.3 & 5.3 & 0.425 & 0.898 & 0.668 \\
\hline Milk energy from body & 8.5 & 18.4 & 11.7 & 5.3 & 0.425 & 0.898 & 0.668 \\
\hline Heat production associated with lactation, $\mathrm{kJ} /\left(\mathrm{d} \cdot \mathrm{BW} W^{0.75}\right)^{8}$ & 289 & 154 & 134 & 60 & 0.321 & 0.248 & 0.970 \\
\hline
\end{tabular}

${ }^{1}$ Data are least squares means

${ }^{2}$ Maximum value of the standard error of the means

${ }^{3}$ Sows with an actual feed intake as percentage of predicted $>75 \%$ during days 4-8 and days 14-18; for over 21-day lactation, sows have energy balance for both early and peak lactation were used

${ }^{4}$ Metabolizable energy (ME) : $\mathrm{ME}_{\text {milk }}(\mathrm{MJ} / \mathrm{d})=\mathrm{ME}_{\text {intake }}(\mathrm{MJ} / \mathrm{d})-\mathrm{ME}_{\text {maintenance }}(\mathrm{MJ} / \mathrm{d})$

${ }^{5}$ Milk energy output from $\operatorname{diet}(\mathrm{MJ} / \mathrm{d})=$ Milk energy output(MJ/d) - Milk energy output from body(MJ/d)

${ }^{6}$ True energy efficiency $(\%)=\frac{\text { Milk energy output from } \operatorname{diet}(\mathrm{MJ} / \mathrm{d})}{\mathrm{ME}_{\text {milk }}(\mathrm{MJ} / \mathrm{d})} \times 100 \%$

${ }^{7}$ Milk energy from $\operatorname{diet}(\%)=\frac{\text { Milk energy output from } \operatorname{diet}(\mathrm{MJ} / \mathrm{d})}{\text { Milk energy }(\mathrm{MJ} / \mathrm{d})}$

${ }^{8}$ Heat production associated with lactation $\left[\mathrm{MJ} /\left(\mathrm{d} \cdot \mathrm{BW}^{0.75}\right)\right]=\frac{\mathrm{ME}_{\operatorname{milk}}(\mathrm{MJ} / \mathrm{d})-\text { milk energy output from } \operatorname{diet}(\mathrm{MJ} / \mathrm{d})}{\mathrm{BW}^{0.75}}$

*Main effect of period (early and late) was significant $(P<0.05)$

${ }^{\dagger}$ Main effect of period (early and late) tended to be significant for true energy efficiency (CON $P=0.086 ;$ OPTLEU $\left.P=0.100\right)$. 
that of Rozeboom et al. [21]. Litter gain (22.4\% and 23.4\% greater) and therefore lactation energy demand was considerably greater in both studies by Pedersen et al. [18, 22], compared to that of the current study reported by Zhang et al. [8]. With the advancement of lactation, BL decreased by $5.9 \%$ [22] from day 3 to 28 , and in our study, BL\% decreased by $0.7 \%$ and $2 \%$ in CON and OPT, respectively, from day 1 to 21 .

Feeding the OPT diet improved apparent and true energy utilization efficiency as well as milk $\mathrm{N}$ output efficiency relative to ME intake in peak lactation. Total energy retained was similar across diets, but sows fed OPT retained less maternal energy, suggesting that OPT diet resulted in more energy partitioning for milk production. Huber et al. [6] indicated that reduced protein diets favored partitioning of AA towards milk protein yield rather than maternal protein pool. This observation may be in part related to a reduced dietary Leu intake, because Leu stimulates maternal body protein gain $[23$, 24]. The decreased milk energy output in OPTLEU compared to OPT during peak lactation combined with no differences in total energy retention across dietary treatments implied that additional Leu above requirement may reduce dietary energy partitioning towards milk. This observation is in line with previously reported performance and $\mathrm{N}$ balance where sows fed $\mathrm{CON}$ and OPTLEU did not lose as much BW as OPT and were in a positive maternal $\mathrm{N}$ balance [8].

The higher NE:ME and ME:DE in peak lactation for OPT fed sows aligns with their improved apparent energy efficiency in peak lactation compared to CON. In addition, the lack of difference in DE:GE in peak lactation indicates that the improvement in apparent efficiency likely occurred during the post-absorptive stage in peak lactation. By definition, urinary energy loss and heat increment represents the difference between "DE to ME" and "ME to NE" [16], suggesting that the improved apparent energetic efficiency in OPT in peak lactation was due to less urinary energy and metabolic heat loss $[4,18]$. In fact, urinary energy loss and estimated heat production associated with lactation in the current study was lower in OPT than CON during the peak lactation period. Other studies on growing-finishing pigs $[4,25]$ and lactating sows $[6,8]$ showed that urinary $\mathrm{N}$ loss decreased by reducing dietary protein. Considering the major contributor of urinary energy is urinary $\mathrm{N}$, primarily from urea [13], less urinary $\mathrm{N}$ loss also implies less urinary energy loss. Previous research in growing pigs also showed a $6.7 \%$ or $100 \mathrm{~kJ} /\left(\mathrm{d} \cdot \mathrm{BW}^{0.65}\right)$ decrease in heat production associated with feeding lower dietary CP [4]. During the entire lactation period, the estimated heat associated with lactation was 289,154 , and $134 \mathrm{~kJ} /$ $\left(\mathrm{d} \cdot \mathrm{BW}^{0.75}\right)$ for CON, OPT and OPTLEU, respectively, corresponding to a $46.7 \%$ or $135 \mathrm{~kJ} /\left(\mathrm{d} \cdot \mathrm{BW}^{0.75}\right)$ reduction in heat between CON and OPT. Note that the total heat production (maintenance + lactation; Fig. 1) added up to be 710,587 , and $546 \mathrm{~kJ} /\left(\mathrm{d} \cdot \mathrm{BW}^{0.75}\right)$ for CON, OPT and OPTLEU, respectively. Those values fall within range of a previously reported value of $669 \mathrm{~kJ} /\left(\mathrm{d} \cdot \mathrm{BW}^{0.75}\right)$ measured by indirect calorimetry and respiratory quotient (RQ)-method to separate heat between sow and litter [26]. Recently, Pedersen et al. [18] estimated heat production (maintenance + lactation) based on milk energy output and a constant lactation efficiency of 0.78 and

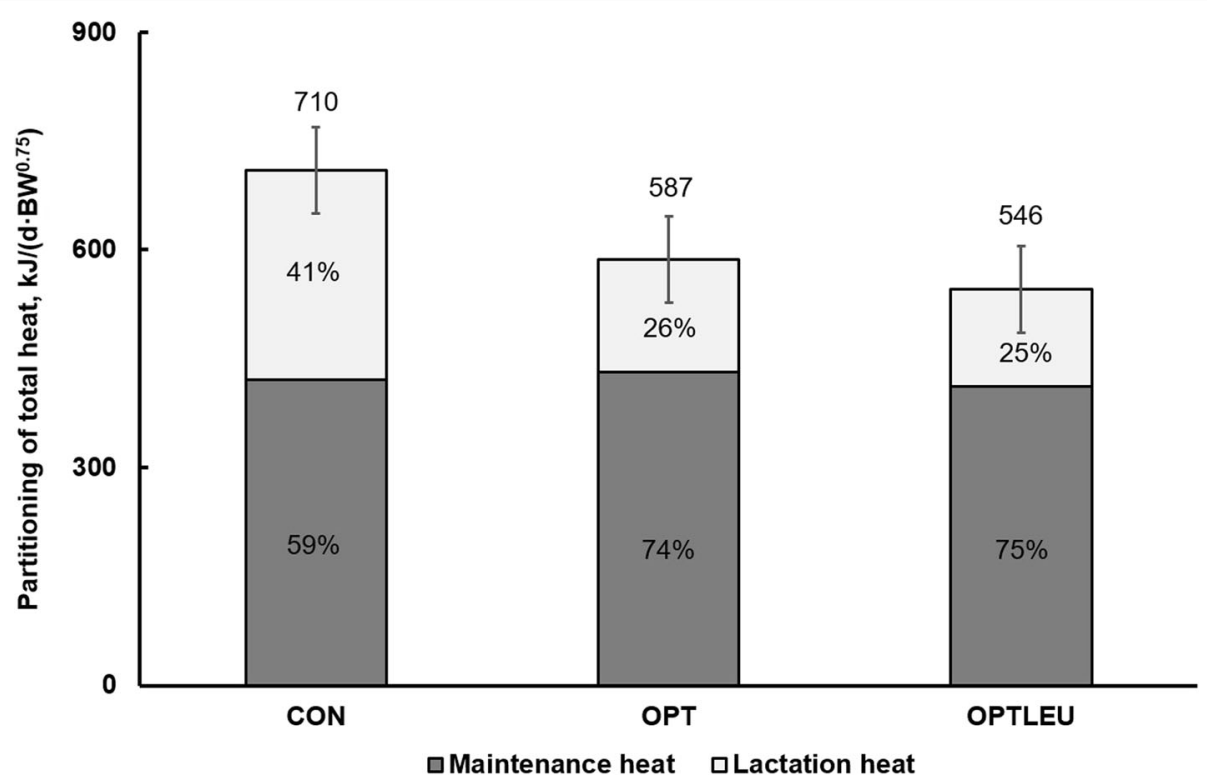

Fig. 1 The partitioning of total heat production of sows fed control (CON), optimal (OPT) and optimal + leucine (OPTLEU) over a 21-day lactation period. Total heat production did not differ between diets 
reported values varying between 757 and $803 \mathrm{~kJ} /$ $\left(\mathrm{d} \cdot \mathrm{BW}^{0.75}\right)$. In our study, the energy efficiency for lactation improved by decreasing dietary $\mathrm{CP}$ and with advancement of lactation. Pedersen et al. [18] did not observe a clear trend in total heat production as dietary CP content decreased, similar to this study. However, our results pointed to less lactation heat as percentage of total heat in OPT (26\%) and OPTLEU (25\%) compared to CON (41\%). Our values and those of Pedersen et al. [18] are theoretical estimates and therefore further testing of the impact of dietary CP concentrations in lactating sows on heat production using indirect calorimetry is needed.

Sow milk energy is partially derived from the diet and partially from the maternal body pool. Dietary energy contribution to milk increased from $77 \%$ to $87 \%$ only in OPT diet as lactation progressed, indicating that the reduced dietary protein with NIAA profile may improve dietary energy partitioning towards milk with advancement of lactation. However, we acknowledge that body mobilization was estimated over a 21-day lactation period, and it was assumed that mobilization rate $(\mathrm{g} / \mathrm{d})$ remained constant throughout lactation. Previous studies [20, 27] indicated that lactating sows mobilized greater amounts of body nutrients in early lactation compared to peak lactation. Similarly, in the present study, sows fed OPT had a negative maternal energy retention $(-0.97 \mathrm{MJ} / \mathrm{d}$ for OPT and $-1.83 \mathrm{MJ} / \mathrm{d}$ for OPTLEU) in early lactation only.

The true efficiency value for sows fed CON for a 21day lactation period was $70.5 \%$, which is fairly close to the estimated NRC [13] value of $72 \%$ for sows fed conventional diets meeting the minimum SID Lys requirement. The true efficiency values of $82 \%$ and $83 \%$ for sows fed OPT and OPTLEU, respectively, did not differ statistically from $\mathrm{CON}$ value of $70.5 \%$, presumably due to the variability associated with body weight loss. Nonetheless, future implementation of those values may impact prediction of energy requirement since the energy prediction model of NRC uses a value of $72 \%$ [13]. Therefore, additional work is needed with a higher number of animals to verify these values and determine whether NIAA diet increases true energy efficiency. The efficiency value of $78 \%$ reported by Pedersen et al. [18] is also higher than NRC [13]. The decrease in true energy efficiency as lactation progressed for CON $(79.9 \%$ to $65.2 \%$ ) and OPTLEU (94\% to $79.5 \%$ ) suggests a potential negative effect of Leu on dietary energy partitioning towards milk, whereby Leu directs dietary energy away from the mammary gland and towards the maternal body. A true efficiency value of $94 \%$ for sows fed OPTLEU in early lactation is somewhat high and puzzling. Note that no higher apparent efficiency was observed, and maternal mobilization was only taken into account in the calculation of true efficiency. Thus, it was likely due to the assumption of constant maternal mobilization, which may be overestimated in early lactation [20, 27]. Nonetheless, efficiency values reported herein for sows fed CON and OPT are within range of other reported values $[13,18]$.

Despite that all three experimental diets were formulated iso-calorically based on the NE system $(10.80 \mathrm{MJ} /$ $\mathrm{kg}$ ), the measured $\mathrm{NE}_{\mathrm{c}}$ (maintenance + lactation) was higher than the calculated values in the low protein diets (OPT or OPTLEU). The present study corrected the NE by excluding the milk energy mobilized from maternal body, because NE is the reflection of dietary energy only [13]. The $\mathrm{NE}_{\mathrm{c}}$ (maintenance + lactation) was previously estimated [18], but the difference between calculated NE and measured $\mathrm{NE}_{\mathrm{c}}$ was not statistically compared. A variation of $\mathrm{NE}_{\mathrm{c}}$ between diets with graded levels of $\mathrm{CP}$ was observed and peaked at CP of $156 \mathrm{~g} / \mathrm{kg}$ [18]. Similarly, the measured $\mathrm{NE}_{\mathrm{c}}$ in the current study was higher in OPT $(138 \mathrm{~g} / \mathrm{kg} \mathrm{CP})$ than CON $(187 \mathrm{~g} / \mathrm{kg} \mathrm{CP})$ during peak lactation. Note that the measured NE only for lactation $\left(\mathrm{NE}_{\text {lactation }}\right)$ in the present study were consistently lower than the calculated values $(10.80 \mathrm{MJ} / \mathrm{kg})$ across all diets. Also, $\mathrm{NE}_{\text {lactation }}$ increased as lactation progressed only in the OPT diet, as reported by Pedersen et al. [18] for $\mathrm{NE}_{\mathrm{c}}$. Such observation raises question regarding the adequacy of the book value of NE for lactating sows which were derived from growing-finishing pigs according to NRC [13]. In fact, sows utilize dietary energy more efficiently for lactation than growing pigs for retention [18]. Whether the calculated NE [13] corresponded to the sum of maintenance and lactation or lactation alone is unclear and either of them differ from the calculated values. The INRA reported NE values of various feed ingredient for both growing pigs and sows, which might serve as additional reference to diet formulation using NE system [28]. However, NE values generated from INRA are based on predictions from nutrient composition and used for both growing pigs and sows. In fact, difference in NE values for growing pigs and sows are carried over by $\mathrm{DE}$ and $\mathrm{ME}$, which are predicted separately for growing pigs and sows. Current results also suggest that NE values for lactating sows are dynamic and dependent on diet (e.g. dietary CP level and AA balance) and stage of lactation of the sow, warranting the need for additional research on the NE system for lactation.

\section{Conclusion}

Feeding a NIAA diet improved the apparent dietary energy utilization due to less urinary energy and metabolic heat loss, a response that was associated with the peak stage of lactation. The estimated value for heat reduction was $154 \mathrm{~kJ} /\left(\mathrm{d} \cdot \mathrm{BW}^{0.75}\right)$ in sows fed a NIAA diet during 
peak lactation. Feeding a NIAA diet also triggered dietary energy deposition into milk at the expense of maternal mobilization, implying higher energy requirement when feeding sows with NIAA diet. Leucine supplementation above requirement may reduce dietary energy utilization for lactation by directing dietary energy away from mammary gland and towards maternal pool, partially explaining the effectiveness in energy efficiency of NIAA diet over high CP diets. The estimated heat production values in this study may need to be validated with indirect calorimetry.

\section{Abbreviations}

AA: Amino acid; BW: Body weight; CP: Crude protein; DE: Digestible energy; GE: Gross energy; IDAA: Indispensable amino acid; ME: Metabolizable energy; NE: Net energy; NIAA: Near ideal amino acid profile; SID: Standardized ileal digestibility

\section{Acknowledgements}

The authors acknowledge Jim Liesman and Dr. Robert Tempelman for their guidance on the statistical analyses, and Kevin Turner and Christopher Rozeboom at the Swine Teaching and Research Center for their assistance with animal husbandry. Authors also wish to acknowledge the generous donation of crystalline amino acids by Ajinomoto Animal Nutrition North America, Inc.

\section{Authors' contributions}

The work was mainly conceived and designed by NLT and SZ. Experimental data were collected and analyzed by SZ and MQ. The manuscript was mainly written by SZ and revised by NLT and JSJ. All the authors contributed to, read and approved the final manuscript.

\section{Funding}

This study was financially supported by USDA-NIFA (award number 201467015-21832)

\section{Availability of data and materials}

The datasets used and/or analyzed during the current study are available from the corresponding author on request.

\section{Ethics approva}

Studies were conducted at the Michigan State University Swine Teaching and Research Center with the approval of Institutional Animal Care and Use Committee (AUF \# 09/12-176-00) at Michigan State University.

\section{Consent for publication}

Not applicable.

\section{Competing interests}

The authors declare no competing financial interest.

\section{Author details}

'Department of Animal Science, Michigan State University, East Lansing 48824, USA. ${ }^{2}$ USDA-ARS Livestock Behavior Research Unit, West Lafayette 47907, USA. ${ }^{3}$ Institute of Animal Husbandry and Veterinary, Hubei Academy of Agricultural Sciences, Wuhan 430064, China.

Received: 21 August 2019 Accepted: 9 December 2019

Published online: 07 February 2020

\section{References}

1. Eissen JJ, Kanis E, Kemp B. Sow factors affecting voluntary feed intake during lactation. Livest Prod Sci. 2000;64:147-65.

2. Strathe AV, Bruun TS, Zerrahn J-E, Tauson A-H, Hansen CF. The effect of increasing the dietary valine-to-lysine ratio on sow metabolism, milk production, and litter growth. J Anim Sci. 2016;94:155-64.
3. Zhang T, Wang L, Shi H, Yan H, Zhang L, Liu X, et al. Heritabilities and genetic and phenotypic correlations of litter uniformity and litter size in large white sows. J Integr Agric. 2016;15:848-54.

4. Le Bellego L, van Milgen J, Dubois S, Noblet J. Energy utilization of lowprotein diets in growing pigs. J Anim Sci. 2001;79:1259-71.

5. Kerr BJ, Yen JT, Nienaber JA, Easter RA. Influences of dietary protein level, amino acid supplementation and environmental temperature on performance, body composition, organ weights and total heat production of growing pigs. J Anim Sci. 2003;81:1998-2007.

6. Huber L, de Lange CFM, Krogh U, Chamberlin D, Trottier NL. Impact of feeding reduced crude protein diets to lactating sows on nitrogen utilization. J Anim Sci. 2015;93:5254-64.

7. Huber L, de Lange CFM, Ernst CW, Krogh U, Trottier NL. Impact of improving dietary amino acid balance for lactating sows on efficiency of dietary amino acid utilization and transcript abundance of genes encoding lysine transporters in mammary tissue. J Anim Sci. 2016;94:4654-65.

8. Zhang S, Qiao M, Trottier NL. Feeding a reduced protein diet with a near ideal amino acid profile improves amino acid efficiency and nitrogen utilization for milk production in sows. J Anim Sci. 2019;97:3882-97.

9. Shennan DB, McNeillie SA, Jamieson EA, Calvert DT. Lysine transport in lactating rat mammary tissue: evidence for an interaction between cationic and neutral amino acids. Acta Physiol Scand. 1994;151:461-6.

10. Calvert DT, Shennan DB. Evidence for an interaction between cationic and neutral amino acids at the blood-facing aspect of the lactating rat mammary epithelium. J Dairy Res. 1996;63:25-33.

11. Guan X, Pettigrew JE, Ku PK, Ames KN, Bequette BJ, Trottier NL. Dietary protein concentration affects plasma arterio-venous difference of amino acids across the porcine mammary gland. J Anim Sci. 2004;82:2953-63.

12. Manjarín R, Zamora V, Wu G, Steibel JP, Kirkwood RN, Taylor NP, et al. Effect of amino acids supply in reduced crude protein diets on performance efficiency of mammary uptake, and transporter gene expression in lactating sows. J Anim Sci. 2012:90:3088-100.

13. NRC. Nutrient requirements of swine. 11th ed. Washington: National Academy Press; 2012.

14. AOAC. Official methods of analysis. 18th ed. Association of Official Chemists: Arlington; 2006

15. Weast RC, Astle MJ, Beyer WH. CRC handbook of chemistry and physics. Boca Raton, FL: CRC Press Inc:; 1984.

16. Ewan RC. Energy utilization in swine nutrition. In: Lewis AJ, Southern LL, editors. Swine nutrition. 2nd ed. Washington: CRC Press; 2001. p. 85-94.

17. Wang Z, Chen Y, Ding J, Liu H, Lyu Z, Dong W, et al. Net energy content of five fiber-rich ingredients fed to pregnant sows. Anim Sci J. 2019;90:939-47.

18. Pedersen TF, Chang CY, Trottier NL, Bruun TS, Theil PK. Effect of dietary protein intake on energy utilization and feed efficiency of lactating sows. $J$ Anim Sci. 2019;97:779-93.

19. Bergsma R, Kanis E, Verstegen MWA, Van der Peet-Schwering CMC, Knol EF. Lactation efficiency as a result of body composition dynamics and feed intake in sows. Livest Sci. 2009:125:208-22.

20. Strathe AV, Bruun TS, Hansen CF. Sows with high milk production had both a high feed intake and high body mobilization. Animal. 2017;11: 1913-21.

21. Rozeboom DW, Pettigrew JE, Moser RL, Cornelius SG, EL Kandelgy SM. In vivo estimation of body composition of mature gilts using live weight, backfat thickness, and deuterium oxide. J Anim Sci. 1994;72: 355-66.

22. Pedersen TF, Bruun TS, Feyera T, Larsen UK, Theil PK. A two-diet feeding regime for lactating sows reduced nutrient deficiency in early lactation and improved milk yield. Livest Sci. 2016;191:165-73.

23. Norton LE, Wilson GJ, Layman DL, Moulton CJ, Garlick PJ. Leucine content of dietary proteins is a determinant of postprandial skeletal muscle protein synthesis in adult rats. Nutr Metab. 2012;9:67-75.

24. Wilkinson DJ, Hossain T, Hill DS, Phillips BE, Crossland H, Williams J, et al. Effects of leucine and its metabolite $\beta$-hydroxy- $\beta$-methylbutyrate on human skeletal muscle protein metabolism. J Physiol. 2013;591:2911-23.

25. Otto ER, Yokoyama M, Ku PK, Ames NK, Trottier NL. Nitrogen balance and ileal amino acid digestibility in growing pigs fed diets reduced in protein concentration. J Anim Sci. 2003:81:1743-53.

26. Jakobsen K, Theil PK, Jørgensen $\mathrm{H}$. Methodological considerations as to quantify nutrient and energy metabolism in lactating sows. J Anim Feed Sci. 2005;14(Suppl 1):31-47. 
27. Theil PK. Transition feeding of sows. In: Farmer $C$, editor. The gestating and lactating sow. Wageningen: Wageningen Academic Publishers; 2015. p. 147-72.

28. Noblet J, Sève B, Jondreville C. Nutritional values for pigs. In: Sauvant D,

Perez JM, Tran G, editors.Tables of composition and nutritional value of feed materials. 2nd ed. INRA; 2004. p. 25-35.

Ready to submit your research? Choose BMC and benefit from:

- fast, convenient online submission

- thorough peer review by experienced researchers in your field

- rapid publication on acceptance

- support for research data, including large and complex data types

- gold Open Access which fosters wider collaboration and increased citations

- maximum visibility for your research: over $100 \mathrm{M}$ website views per year

At BMC, research is always in progress.

Learn more biomedcentral.com/submissions 